\title{
Flower Bud Abscission Reduced in Hibiscus Sabdariffa by Radiation from GSM Mast
}

\author{
Ayoola O. Oluwajobi ${ }^{1,2}$, Olamide A. Falusi ${ }^{1} \&$ Nuha A. Zubbair ${ }^{2}$ \\ ${ }^{1}$ Department of Biological Sciences, School of Natural and Applied Sciences, Federal University of Technology, \\ Minna, Nigeria \\ ${ }^{2}$ Department of Biology, Institute of Applied Sciences, Kwara State Polytechnic, Ilorin, Nigeria \\ Correspondence: Ayoola O. Oluwajobi, Department of Biological Sciences, School of Natural and Applied \\ Sciences, Federal University of Technology, Minna, Nigeria. Tel: 234-803-503-6877. E-mail: \\ segunoluwajobi@yahoo.com
}

Received: October 14, 2014 Accepted: November 10, 2014 Online Published: December 29, 2014

doi:10.5539/ep.v4n1p53 URL: http://dx.doi.org/10.5539/ep.v4n1p53

\begin{abstract}
Radiation from GSM mast is regarded as a harmless but has recently generated a lot of controversies on its bio safety. Roselle naturally has about $50 \%$ flower bud abscission rate, however, this research work is aimed at investigating the influence of radiation from $900 \mathrm{MHz}$ GSM mast on the rate of flower bud production and abscission in Hibiscus sabdariffa. The plants exposed to the mast radiation generally produced significantly lower number of flower buds per plant (ranging from $80.00 \pm 9.62$ to $106.80 \pm 8.17$ ) than the control plants (107.80 \pm 15.21$)$. Exceptions were found in locations A $100 \mathrm{~m}, 400 \mathrm{~m}$ and location B $100 \mathrm{~m}$ where the values were slightly higher $(129.20 \pm 34.97,138.40 \pm 19.50$ and $118.80 \pm 15.80$ buds / plant respectively). Abscission in control plants was $55.6 \%$ per plant while in the exposed plants, a range of 40.33 to $48.21 \%$ were obtained. Weak correlations exist between EMF intensities and abscission rate. The significant $(\mathrm{p} \leq 0.05)$ reductions obtained in flower bud abscission in Hibiscus sabdariffa due to radiation from the GSM mast creates ecological stability for the plant whereby it enhances fruit formation and therefore increases the yield of the plant. If properly harnessed the radiation may play useful roles in the generation of variability and also in plant improvement.
\end{abstract}

Keywords: GSM, mast, radiation, flower bud, abscission, Hibiscus sabdariffa, variability

\section{Introduction}

Roselle (Hibiscus sabdariffa L.) belongs to the family Malvaceae of the Angiospermae and it is one of the most important and popular food, medicinal and industrial plants whose calyx and leaves are widely eaten. Its members are rich in anthocyanin and organic acids (Hong \& Wrost-lad, 1990; Gomez-Leyva et al., 2009). It is also widely used as additives in the manufacture of several products such as liquor, jellies and jams (Akindahunsi \& Olaleye, 2003) and the plant is drought tolerant (Torres-Moranet et al., 2011). Hibiscus sabdariffa is an herbaceous annual plant which is generally cultivated for its fruit (calyces) and leaves. It is a tropical region plant but now widely grown in many regions of the world (Duke, 1983; Morton, 1987). It is also a popular vegetable crop grown widely in Nigeria with several varieties (Falusi, 2004; 2008). Cisse et al. (2009) reported that the plant play important roles in income generation and subsistence among rural farmers in developing countries through the sale of the calyces and leaves.

Qi, Chin, Malekian, Berhane and Gager (2005); Hussein, Shahein, El-Hakim and Awad (2010) reported that Hibiscus sabdariffa has considerable industrial, pharmaceutical and economic values in several countries around the world. It is commonly used to make jelly, jam, juice, wine, syrup, gelatin, pudding, cake, ice cream and flavours. Many medicinal applications of the plant have been developed around the world in the treatment of hypertension, pyrexia, liver damage and leukaemia because of its high content of polyphenols (Tseng et al., 2000; Odigie, Ettarh, and Adigun, 2003). Also, it is a source of vegetable oil (from the seeds) that is low in cholesterol and rich in other phytosterols and tocopherols. The global characteristics of Roselle and seed oil allow important industrial applications for this oil. These characters represent added values for the culture of this plant (Mohamed, Fernadez, Pineda \& Aguilar, 2007). The fleshy calyces of the flowers (sepals) have pleasant acid taste and are used as a beverage crop in many countries in form of mild laxatives. 
Roselle is popularly grown for its fruits; especially the calyces, however, Falusi et al. (2014) reported a relatively low fruit production in six accessions of Roselle grown in Nigeria. Except in only one accession where a mean fruit set of 58.16 / plant was obtained, other accessions produced less than 50 fruits / plant, mostly a range from 33.50 to 58.16 fruits / plant.

Many factors are important for fruiting of crops which ranges from genetic (intrinsic) to the various environmental conditions. Abortion of flowers, flower buds and fruits according to Wien, Tripp and Hernandez-Armenta (1989) is an important factor that influences yield in many crops including pepper. They also identified several environmental stresses associated with fruit abortion. These include heat, drought and low light conditions however; with the recent introduction of mobile telephony, the increasing proliferation of telecommunications antennae and the attendant increase in complaints associated with the system has called for serious public scrutiny, despite the benefits of the system to humanity.

Although the transmitting power of the telecommunications system is relatively very low, a weak electromagnetic radiation with no heating effect, its pulsating nature of emissions which synchronises with the physiological systems is of concern. Hyland (2000, 2003), a physicist and executive member of International Institute of Biophysics in Germany, has earlier reported that the pulsed microwave radiation used in the GSM systems of telecommunications is characterised by a number of particularly well defined frequencies, a feature that can greatly enhance its impact on the biochemistry of the body and facilitate its discernment against the heat radiation that is emitted by the body which actually depends on its physiological temperature. There have been reports of the impact of the emissions from GSM antennae on both man, animals and plants (Santini, Santini, Le Ruz, Danze \& Seigne, 2003; Panogopoulos \& Margaritis, 2006; Haggerty, 2010).

In view of the above, this study examines the impact of the radiation from GSM mast on flower bud abscission in H. sabdariffa.

\section{Materials and Methods}

\subsection{Experimental Sites}

Three locations were chosen each with at least a $900 \mathrm{MHz}$ GSM mast and they were free from obstructions such as buildings and trees. The locations were named $\mathrm{A}\left(06^{\circ} 31^{\prime} 36.9^{\prime \prime} \mathrm{E}\right.$ and $\left.09^{\circ} 39^{\prime} 17.8^{\prime \prime} \mathrm{N}\right), \mathrm{B}\left(06^{\circ} 27^{\prime} 35.2^{\prime \prime} \mathrm{E}\right.$ and $\left.09^{\circ} 32^{\prime} 15.9^{\prime \prime} \mathrm{N}\right)$ and $\mathrm{C}\left(06^{\circ} 32^{\prime} 16.7^{\prime \prime} \mathrm{E}\right.$ and $\left.09^{\circ} 37^{\prime} 13.6^{\prime \prime} \mathrm{N}\right)$ while another location $\left(06^{\circ} 22^{\prime} 29.5^{\prime \prime} \mathrm{E}\right.$ and $09^{\circ} 42^{\prime}$ $\left.31.6^{\prime \prime} \mathrm{N}\right)$, without any GSM signals was chosen as the control site.

\subsection{Techniques}

The soil used in raising the plants was collected from a garden, mixed with poultry droppings and left for four weeks to properly decompose and homogenise. The soil was turned weekly.

Five viable seeds were sowed in each of the eleven litres sized plastic bucket containing $9000 \mathrm{~cm}^{3}$ of the soil and the buckets were placed at $100 \mathrm{~m}, 200 \mathrm{~m}, 300 \mathrm{~m}$ and $400 \mathrm{~m}$ from the mast. The buckets were labelled according to location and distance from the mast. For instance, the three buckets placed in location A at $100 \mathrm{~m}, 200 \mathrm{~m}, 300$ $\mathrm{m}$ and $400 \mathrm{~m}$ away from the mast were labelled $1 \mathrm{~A}_{1}, 1 \mathrm{~A}_{2}, 1 \mathrm{~A}_{3} ; 2 \mathrm{~A}_{1}, 2 \mathrm{~A}_{2}, 2 \mathrm{~A}_{3} ; 3 \mathrm{~A}_{1}, 3 \mathrm{~A}_{2}, 3 \mathrm{~A}_{3}$ and $4 \mathrm{~A}_{1}, 4 \mathrm{~A}_{2}, 4 \mathrm{~A}_{3}$ respectively. The plants in locations $\mathrm{B}, \mathrm{C}$ and the control were all labelled following the same patterns. However, in the control location, the three spots chosen were five hundred meters apart. Cages made of wood and chicken mesh were placed to delineate and also to protect the experiments at each site from ranging animals such as goats, sheep and cattle. The experimental design used was Randomised Block Design. The number of flower buds produced in 30 days were estimated by visual counting while the number of buds aborted within the same period were estimated using the formula below:

$$
\% \text { Bud abortion }=\frac{\text { Number of buds aborted }}{\text { Total number of buds produced }} \times 100
$$

The intensity of the radiofrequency radiations from the GSM mast was measured in each location and at the specific distances $(100 \mathrm{~m}, 200 \mathrm{~m}, 300 \mathrm{~m}$ and $400 \mathrm{~m})$ considered for the experiment. The instrument used was the Acoustimeter (RF meter), Model AM-10 manufactured by EMFields, UK. The measurement sensitivity is $0.02-$ $6.0 \mathrm{~V} / \mathrm{m}\left(1-100,000 \mu \mathrm{W} / \mathrm{m}^{2}\right)$. An average power density and peak hold (measured as the average of 1024 samples in 0.35 secs) were recorded for each study spot throughout the period of the experiment.

\section{Results}

The control plants produced a mean flower bud of $107.80 \pm 15.21$ per plant in 30 days (Table 1) while plants from other locations and distances to the mast produced significantly lower number of buds (ranging from $80.00 \pm 9.62$ 
to $106.80 \pm 8.17$ ) except in locations A $100 \mathrm{~m}, 400 \mathrm{~m}$ and location B $100 \mathrm{~m}$ where the values were slightly higher (129.20 $\pm 34.97,138.40 \pm 19.50$ and $118.80 \pm 15.80$ buds / plant respectively).

Table 1 . Number of flower bud production in thirty days in $H$. sabdariffa in relation to distance from GSM mast

\begin{tabular}{llcccc}
\hline & & \multicolumn{5}{c}{ Distance (m) } \\
Locations & Control & $\mathbf{1 0 0}$ & $\mathbf{2 0 0}$ & $\mathbf{3 0 0}$ & $\mathbf{4 0 0}$ \\
\hline $\mathbf{A}$ & $107.80 \pm 15.21^{\mathrm{bc}}$ & $129.20 \pm 34.97^{\mathrm{cd}}$ & $80.00 \pm 9.62^{\mathrm{a}}$ & $87.20 \pm 8.41^{\mathrm{ab}}$ & $138.40 \pm 19.50^{\mathrm{d}}$ \\
$\mathbf{B}$ & $107.80 \pm 15.21^{\mathrm{b}}$ & $118.80 \pm 15.80^{\mathrm{b}}$ & $88.40 \pm 6.54^{\mathrm{a}}$ & $80.40 \pm 12.99^{\mathrm{a}}$ & $106.80 \pm 8.17^{\mathrm{b}}$ \\
$\mathbf{C}$ & $107.80 \pm 15.21^{\mathrm{d}}$ & $101.00 \pm 9.92^{\mathrm{cd}}$ & $93.60 \pm 3.05^{\mathrm{bc}}$ & $78.60 \pm 8.38^{\mathrm{a}}$ & $83.80 \pm 7.79^{\mathrm{ab}}$ \\
\hline
\end{tabular}

Means in the same row with different superscripts are significantly different $(\mathrm{p} \leq 0.05)$.

The percentage bud abortion per plant within 30 days of bud emergence in $H$. sabdariffa showed that there was more bud abortion in the control plants $(50.66 \%)$ than those obtained from the plants exposed to ray emissions from the $900 \mathrm{MHz}$ GSM antennae as shown in Table 2. Plants from location A gave a range of $40.33 \%(100 \mathrm{~m})$ to $48.04 \%(200 \mathrm{~m})$. In location $\mathrm{B}$, it was $43.18 \%(100 \mathrm{~m})$ to $48 \%(300 \mathrm{~m})$ while in location $\mathrm{C}$; it was $45.48 \%$ $(100 \mathrm{~m})$ to $48.21 \%(400 \mathrm{~m})$. All samples exposed to radiations from GSM mast in all locations gave significantly lower abscission rate than the control $(\mathrm{p} \leq 0.05)$. Table 3 shows very weak positive correlations between percentage bud abortions and EMF intensities of the ray emissions at various distances from the mast while figure 1 shows the photograph of aborted flower buds.

Table 2. Flower bud abscission (\%) in thirty days in H. sabdariffa in relation to distance from $900 \mathrm{MHz}$ GSM mast

\begin{tabular}{cccccc}
\hline & & \multicolumn{5}{c}{ Distance (m) } \\
Locations & Control & $\mathbf{1 0 0}$ & $\mathbf{2 0 0}$ & $\mathbf{3 0 0}$ & $\mathbf{4 0 0}$ \\
\hline A & $50.66 \pm 6.42^{\mathrm{c}}$ & $44.33 \pm 3.91^{\mathrm{a}}$ & $48.04 \pm 3.32^{\mathrm{b}}$ & $47.45 \pm 5.39^{\mathrm{b}}$ & $45.43 \pm 3.38^{\mathrm{a}}$ \\
B & $50.66 \pm 6.42^{\mathrm{c}}$ & $43.18 \pm 3.39^{\mathrm{a}}$ & $47.74 \pm 6.41^{\mathrm{b}}$ & $48.00 \pm 4.91^{\mathrm{b}}$ & $44.22 \pm 5.24^{\mathrm{a}}$ \\
C & $50.66 \pm 6.42^{\mathrm{c}}$ & $45.48 \pm 8.25^{\mathrm{a}}$ & $47.53 \pm 3.74^{\mathrm{b}}$ & $47.73 \pm 1.78^{\mathrm{b}}$ & $48.21 \pm 7.08^{\mathrm{b}}$ \\
\hline
\end{tabular}

Means in the same row with different superscripts are significantly different $(\mathrm{p} \leq 0.05)$

Table 3. Correlation coefficient (r) between flower bud abortion in H. sabdariffa and EMF intensities in study locations in relation to distance from GSM Mast

\begin{tabular}{|c|c|c|c|c|c|c|c|}
\hline \multirow[b]{2}{*}{ Distance (m) } & & \multicolumn{2}{|c|}{ Location A } & \multicolumn{2}{|c|}{ Location B } & \multicolumn{2}{|c|}{ Location C } \\
\hline & & Mean \pm SD & $\mathbf{r}$ & Mean \pm Sd & $\mathbf{r}$ & Mean \pm Sd & $\mathbf{r}$ \\
\hline \multirow[t]{2}{*}{100} & EMF (V/m) & $0.80 \pm \mathbf{0 . 1 9}$ & -0.662 & $0.41 \pm \mathbf{0 . 1 1}$ & -0.457 & $0.85 \pm 0.13$ & -0.121 \\
\hline & $\%$ Bud abortion & $44.33 \pm 3.91$ & & $43.18 \pm 3.39$ & & $45.48 \pm 8.25$ & \\
\hline \multirow[t]{2}{*}{200} & EMF (V/m) & $\mathbf{0 . 7 0 \pm 0 . 0 5}$ & 0.119 & $\mathbf{0 . 4 7 \pm 0 . 2 4}$ & -0.016 & $0.92 \pm 0.31$ & 0.037 \\
\hline & $\%$ Bud abortion & $48.04 \pm 3.32$ & & $47.74 \pm 6.41$ & & $47.53 \pm 3.74$ & \\
\hline \multirow[t]{2}{*}{300} & $\mathrm{EMF}(\mathrm{V} / \mathrm{m})$ & $1.12 \pm 0.22$ & -0.053 & $0.61 \pm \mathbf{0 . 2 6}$ & 0.467 & $1.08 \pm 0.8$ & -0.454 \\
\hline & $\%$ Bud abortion & $47.45 \pm 5.39$ & & $48.00 \pm 4.91$ & & $47.73 \pm 1.78$ & \\
\hline \multirow[t]{2}{*}{400} & $\mathrm{EMF}(\mathrm{V} / \mathrm{m})$ & $\mathbf{0 . 9 0 \pm 0 . 2 9}$ & 0.085 & $\mathbf{0 . 7 2} \pm \mathbf{0 . 3 5}$ & 0.269 & $1.05 \pm 0.47$ & 0.339 \\
\hline & $\%$ Bud abortion & $45.43 \pm 3.38$ & & $44.22 \pm 5.24$ & & $48.21 \pm 7.08$ & \\
\hline
\end{tabular}




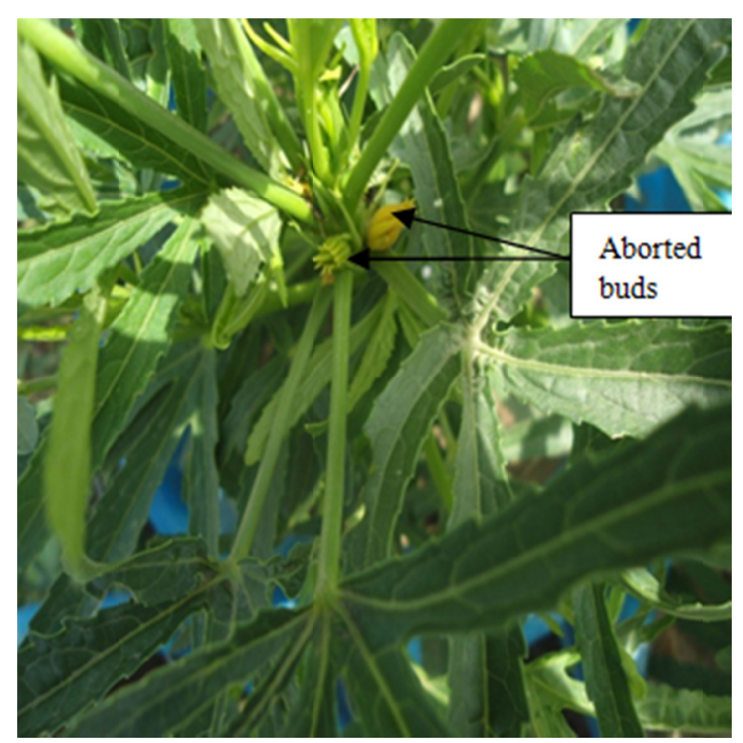

Figure 1. Aborted flower bud in H. sabdariffa

\section{Discussion}

Flower buds are the sexual reproductive structures of the plants that eventually gives rise to the seeds and fruits. Mohamed et al. (2011) reported that gamma irradiation of $H$. sabdariffa showed significant difference on the number of fruits per plant among the varieties at $p<0.01$. Marcelis, Heuvelink and Baan Hofman-Eijer (2004) reported that shading, changes in temperature, plant density, position of earlier formed fruits and leaf pruning, all affected flower and fruit abortion in sweet pepper (Capsicum annuum L.). Flower bud production was significantly lower in plants exposed to radiation from the GSM mast than the number obtained for the unexposed plants. This reduction will normally affect the total number of fruits produced by the plant, hence its yield. However, flower bud abscission in 30 days showed that the abortion of buds in the control plant (50.66 \%) was significantly higher than those obtained in all the plants exposed to GSM mast radiation (40.33 to $48.21 \%$ ) at $\mathrm{p} \leq 0.05$. Aborted buds cannot develop into fruits; therefore the reduction of bud abortion tend to counteract the impact of the reduced bud production in the plant, thus an advantage to $H$. sabdariffa as it will boost fruit formation and by implication yield of the plant.

\section{Conclusion}

This study showed that the radiation from $900 \mathrm{MHz}$ GSM mast has impact on H. sabdariffa by reducing the flower bud production and abscission. The reduction in flower bud formation is a negative impact while the reduction in its abscission is a positive impact. These attributes of the radiation thus created an ecological stability in the plant, and if properly harnessed may play useful roles in the generation of variability and also in plant improvement programmes.

\section{Acknowledgements}

The assistance of Messrs Jerry Simon and Felix Maigida of the Federal University of Technology, Minna, Nigeria towards the success of the experiment is acknowledged.

\section{References}

Akindahunsi, A. A., \& Olaleye, M. T. (2003). Toxicological investigation of aqueous-methanolic extract of the $\begin{array}{lllllll}\text { calyces of Hibiscus sabdariffa L. } J \text { Ethnopharmacology, } & \text { 89, } & \text { 61-164. }\end{array}$ http://dx.doi.org/10.1016/S0378-8741(03)00276-9

Cissé, M., Dornier, M., Sakho, M., N'Diaye, A., Reynes, M., \& Sock, O. (2009). Lebissap (Hibiscus sabdariffa L.) composition et principales utilisations. Fruits, 64(3), 179-193. http://dx.doi.org/10.1051/fruits/2009013

Duke, J. A. (1983). Handbook of Energy Crops. Retrieved February 21, 2014, from http://www.hort.purdue.edu/newcrop/ duke energy

Falusi, O. A. (2004). Collecting Roselle (Hibiscus sabdariffa L.) Germplasm in Nigeria. J Arid Agric, 14, 81-83.

Falusi, O. A. (2008). Inheritance of Characters in Kenaf (Hibiscus canabinus). Afri. J. Biotechnol, 7(7), 904-906. 
http://dx.doi.org/10.5897/AJBO7.694

Falusi, O. A., Dangana, M. C., Daudu, O. A. Y., Oluwajobi, A. O., Abejide, D. R., \& Abubakar, A. (2014). Evaluation of some Rossele (Hibiscus sabdariffa L.) germplasm in Nigeria. International Journal of Biotechnology and Food Science, 2(1), 117-121.

Gomez-Leyva, J. F., Acosta, L. A. M., Muraira, I. G. L., Espino, H. S., Ramirez-Cervantes, F., \& Andrade-Gonzalez, M. (2008). Multiple shoot regeneration of Roselle (Hibiscus sabdariffa L.) from shoot apex culture system. International Journal of Botany, 4(3), 326-330. http://dx.doi.org/10.3923/ijb.2008.326.330

Haggerty, K. (2010). Adverse Influence of Radio Frequency Background on Trembling Aspen Seedlings: Preliminary Observations. International Journal of Forestry Research, 1-7. http://dx.doi.org/10.1155/2010/836278

Hong, V., \& Wrost-lad, O. (1990). Use of HPLC separation/photodiode array detection for characterisation of anthocyanin. Journal of Agriculture and Food Chemistry, 38, 708-715. http://dx.doi.org/10.1021/jf00093a026

Hussein, R. M., Shahein, Y., El-Hakim, \& Awad, H. M. (2010). Biochemical and Molecular Characterisation of three coloured types of roselle (Hibiscus sabdariffa). Journal of American Science, 6(11), 726-733.

Hyland, G. J. (2000). The Physics and Biology of Mobile Telephony. The Lancet, 356, 1833-1836. http://dx.doi.org/10.1016/S0140-6736(00)03243-8

Hyland, G. J. (2003). How exposure to GSM and TETRA Base Stations Radiations can adversely affect Humans. Retrieved August 6, 2014, from http:/www.mastsanity.org/documents/ cluster2003.doc

Marcelis, L. F., Heuvelink, M., \& Baan Hofman-Eijer, E. (2004). Flower and fruit abortion in sweet pepper in relation to source and sink strength. Journal of Experimental Botany, 55(406), 2261-2268. http://dx.doi.org/10.1093/jxb/erh245

Mohamed, R., Fernadez, J., Pineda, M., \& Aguilar, M. (2007). Roselle (Hibiscus sabdariffa) seed oil a rich source of $\gamma$-tocopherol. Journal of Food Science, 72, 207-211. http://dx.doi.org/10.1111/j.1750-3841.2007.00285.x

Morton, J. (1987). Roselle. In Fruits of Warm Climates. Retrieved August 7, 2013, from http://www.hort.purdue.edu/newcrop/ morton/roselle.html

Odigie, I. P., Ettarh, R. R., \& Adigun, S. (2003). Chronic administration of aqueous extract of Hibiscus sabdariffa attenuates hypertension and reverses cardiac hypertrophy in $2 \mathrm{~K}-1 \mathrm{C}$ hypertensive rats. Journal of Ethnopharmacology, 86, 181-185. http://dx.doi.org/10.1016/S0378-8741(03)00078-3

Panagopoulos, D. J., \& Margaritis, L. (2006). Effects of different kinds of electromagnetic fields on the offspring production of Insect. $2^{\text {nd }}$ International Workshop on Biological effects of Electromagnetic field, pp. $348-452$.

Qi, Y., Chin, K. L., Malekian, F., Berhane, M., \& Gager, J. (2005). Biological Characteristics, Nutritional and Medicinal Values of Roselle, Hibiscus sabdariffa. Circular: Urban Forestry Natural Resources and Environment No 604. Retrieved May 14, 2014, from http://www.suagcenter.com

Santini, R., Santini, P., Le Ruz, P., Danze, J. M., \& Seigne, M. (2003). Survey study of people living in the vicinity of Cellular Base Stations. Electromagnetic Biology and Medicine, 22(1), 41-49. http://dx.doi.org/10.1081/JBC-120020353

Torres-Moran, M. I., Escoto-Delgadillo, M., Ron-Parra, J., Parra-Tovar, G., Mena Munguia, S., Rodriguez-Garcia, A. ... Castellanos-Hernandez, Y. (2011). Relationships among twelve genotypes of Roselle (Hibiscus sabdariffa L.) cultivated in western Mexico. Industrial Crops and Products, 34, 1079-1083. http://dx.doi.org/10.1016/j.indcrop.2011.03.020

Tseng, T., Kao, T., Chu, C., Chou, F., Lin, W., \& Wang, C. (2000). Induction of apoptosis by Hibiscus Protocatechuic Acid in Human Leukemia Cells via Reduction of Retinoblastoma (RB) Phosphorylation and $\begin{array}{llll}\text { Bcl-2 Expression. } & \text { Biochemical } & \text { Pharmacology, 60, }\end{array}$ http://dx.doi.org/10.1016/S0006-2952(00)00322-1

Wien, H. C., Tripp, K. E., \& Hernandez-Armenta, R. (1989). Abscission of reproductive structures in pepper: Causes, mechanisms and control. In S. K. Green, (Ed.), Tomato and pepper production in the tropics (pp. 150-165). Taipei, Taiwan, R.O.C: Asian Research and Development Center. 


\section{Copyrights}

Copyright for this article is retained by the author(s), with first publication rights granted to the journal.

This is an open-access article distributed under the terms and conditions of the Creative Commons Attribution license (http://creativecommons.org/licenses/by/3.0/). 